\title{
SPROUTS CONTAIN HIGHER TOTAL PHENOLICS, TOTAL FLAVONOIDS, AND ANTIOXIDANT ACTIVITY THAN SEED IN DIFFERENT THAI VARIETIES OF MUNGBEANS (Vigna Radiata L.)
}

\author{
MARATREE PLAINSIRICHAI*, CHUTIMA KHRAMSUNGNOEN AND JIRAPORN \\ KRASAETEP
}

Department of Agricultural Technology, Faculty of Technology, Mahasarakham University, Khamring, Kantarawichai, Maha Sarakham 44150 Thailand.

*Corresponding author: maratree.p@msu.ac.th

Submitted final draft: 7 January 2021 Accepted: 26 January 2021

http://doi.org/10.46754/jssm.2021.06.002

\begin{abstract}
It has been reported that mungbean seeds contain fat, protein, lecithin and amino acids, but the study of antioxidants and their activity in those seeds, particularly in comparison to the sprouts of Thai mungbean varieties, is rare. This research studied the antioxidants and antioxidant activity in seeds and sprouts of five Thai mungbean varieties (Vigna radiata L.), namely Chainat 36, Chainat 72, Chainat 84-1, M.T.S 1 and Kamphaengsaen 2. Total phenolics, total flavonoids, chlorophyll $a$, chlorophyll $b$, total chlorophyll and antioxidant activity (DPPH) in the seeds and sprouts were analyzed. The experiment protocols were arranged as a completely randomized design (CRD) $(n=4)$. There was low variation of total phenolics, total flavonoids, chlorophyll $a$, chlorophyll $b$, total chlorophyll and DPPH radical scavenging in the seeds of all mungbean varieties. However, they increased sharply with germination. At Day 4, Chainat 36 sprouts were found to contain the highest total phenolics and total flavonoids $(3,372.8 \mathrm{mg}$ GAE/100g of DW and 6,808.6 mg QE/100g of DW, respectively), which were significantly higher than those in seeds and sprouts at other germination stages. The total phenolics in Chainat 36 also increased sharply by almost six-fold compared with the previous day, whereas it was three-fold in other varieties. The DPPH radical scavenging in the seeds of all varieties was low, but increased sharply during germination. The sprouts at Day 4 had significantly higher antioxidant activity than in seeds by almost 30 -fold. At the same day, the highest DPPH radical scavenging was observed in the sprouts of M.T.S 1. In conclusion, antioxidants and their activity are low in mungbean seeds. After germinating, especially at Day 4, total phenolics and total flavonoids would rise significantly, especially in Chainat 36 . This indicated that Thai mungbean sprouts are a good source of nutrition and health.
\end{abstract}

Keywords: Phenolics, flavonoids, antioxidant activity, mungbean, seed, sprout.

\section{Introduction}

Oxidants are unstable molecules that are sensitive to chemical reaction and harmful to human health (Pizzino et al., 2017). They can continuously leave a deteriorative effect on cells and tissues (Wu et al., 2013). The human body is constantly exposed to such elements and can neutralize its effects by using bioactive compounds (Pizzino et al., 2017). Antioxidants can protect cells through three mechanisms, namely preventing, scavenging and chainbreaking of the oxidization process. Generally, bioactive compounds can be obtained by eating a good amount of fruits, vegetables, seeds and sprouts (Wu et al., 2013).
Mungbeans (Vigna radiata L; Fabaceae) are grown in countries like India, China and Thailand (Shi, 2016), which use it as an ingredient in many local dishes. It can be grown in all types of soil and under warm climate up to $35^{\circ} \mathrm{C}$. Mungbeans can be harvested after 75 to 90 days, which makes it a suitable rotation crop (Liu, 2006; Lim, 2012). They are commonly consumed as seeds and sprouts in Asia and Europe (Tang et al., 2014). The mungbean seed contains 20-25\% protein and 55-65\% carbohydrate dry weight (Tang, 2014; Kudre et al., 2013; Nair et al., 2013). It also contains tannins, phytic acid, trypsin inhibitors and hemagglutinin (Lin, 1997). Most importantly, the seeds contain 
bioactive compounds like flavonoids (flavones, isoflavones, and isoflavonoids), phenolic acids (gallic acid, vanillic acid, caffeic acid, cinnamicacid, protocatechuic acid, shikimic acid, p-hydroxybenzoicacid) and many other organic acids (Anwar et al., 2007).

The Thai mungbean Chainat 84-1 is obtained by irradiating Chainat 36 with gammaray at $500 \mathrm{~Gy}$. The seed is large and suitable for producing sprouts. Seed weight is $69 \mathrm{~g} / 1,000$ seeds, which is higher than the original Chainat 36 and Kampangsan 1 varieties. When it is used to produce sprouts, its fresh weight is higher than the two latter varieties. The taste of the sprouts is also sweeter (Department of Agriculture, n.d.).

However, the study of antioxidants and antioxidant activity in Thai mungbean varieties is rare. Therefore, the objective of this research is to quantify the antioxidants and their activity in mungbean seeds and sprouts. It is hypothesised that there will be significant variation of antioxidants and antioxidant activity in seeds and sprouts of different mungbean varieties.

\section{Materials and Methods}

\section{Experiment Setup}

The experiment was designed according to a completely randomized design (CRD) protocol with four replications. Seeds of five mungbean varieties were used, namely Chainat 36 , Chainat 72, Chainat 84-1, M.T.S 1 and Kamphaengsaen (KPS) 2. The seeds were placed in a moist environment and allowed to germinate for four days (Day 1 to Day 4).

\section{Extraction of Crude Antioxidants}

Antioxidants were extracted from seeds and sprouts daily throughout the germination period. A total of $5 \mathrm{~g}$ of mungbean seeds or sprouts were crushed and placed in Erlenmeyer flasks before adding $20 \mathrm{ml}$ of $1 \%$ hydrochloric acid in ethyl alcohol. The flasks were shaken before being allowed to rest at room temperature for $18 \mathrm{hrs}$. The solutions, which had a mungbean extract concentration of $0.25 \mathrm{~g} / \mathrm{ml}$, was then filtered and stored below $4^{\circ} \mathrm{C}$.

\section{Determination of antioxidants}

\section{Total phenolic content}

The procedures to determine total phenolic content were optimized from Javanmardi et al. (2003). Standard solution of gallic acid was prepared at concentrations of $0.025,0.05,0.1$, $0.2,0.4,0.8$ and $1.6 \mathrm{mg} / \mathrm{ml}$. A stock solution was prepared by dissolving $0.051 \mathrm{~g}$ gallic acid powder in $25 \mathrm{ml}$ water. The desired concentrations were achieved by taking the following volumes of the stock solution and topping them up with ethyl alcohol to $1 \mathrm{ml}$ : $0.125 \mathrm{ml}$ (for $0.025 \mathrm{mg} / \mathrm{ml}$ ), $0.025 \mathrm{ml}(0.05 \mathrm{mg} / \mathrm{ml}), 0.05 \mathrm{ml}(0.1 \mathrm{mg} / \mathrm{ml}), 0.1$ $\mathrm{ml}(0.2 \mathrm{mg} / \mathrm{ml}), 0.2 \mathrm{ml}(0.4 \mathrm{mg} / \mathrm{ml}), 0.4 \mathrm{ml}(0.8$ $\mathrm{mg} / \mathrm{ml})$ and $0.8 \mathrm{ml}(1.6 \mathrm{mg} / \mathrm{ml})$.

A total of $50 \mu 1$ of each mungbean extract was added to $2.5 \mathrm{ml}$ of $10 \%$ Folin-Ciocalteau reagent and shaken before leaving at room temperature for $15 \mathrm{~min}$. Then $2 \mathrm{ml}$ of $7.5 \%$ sodium bicarbonate $\left(\mathrm{Na}_{2} \mathrm{CO}_{3}\right)$ was added into the solutions before being shaken again and left at room temperature for another 15 minutes. The solutions' absorbance was then measured using a spectrophotometer at a wavelength of $765 \mathrm{~nm}$.

The total phenolic content for each extract was then derived from the absorbance curve of the standard solution. The results of all extracts were described as mg of gallic acid equivalent per one hundred grammes of dry weight ( $\mathrm{mg}$ GAE/100g of DW).

\section{Total Flavonoid Content}

Determination of flavonoid content was optimized from Yang et al. (2009). A standard solution of Quercetin at concentrations of 0.025 , $0.05,0.1,0.2,0.4,0.8$ and $1.6 \mathrm{mg} / \mathrm{ml}$ were prepared from a stock solution by mixing $0.05 \mathrm{~g}$ of Quercetin powder in $25 \mathrm{ml}$ of distilled water. The desired concentrations were achieved by pipetting the following volumes from the stock solution and topped up with ethyl alcohol to 3 $\mathrm{ml}: 0.01875 \mathrm{~mL}$ (for $0.025 \mathrm{mg} / \mathrm{ml}$ ), $0.075 \mathrm{ml}$ $(0.05 \mathrm{mg} / \mathrm{ml}), 0.15 \mathrm{ml}(0.1 \mathrm{mg} / \mathrm{ml}), 0.3 \mathrm{ml}(0.2$ $\mathrm{mg} / \mathrm{ml}), 0.6 \mathrm{ml}(0.4 \mathrm{mg} / \mathrm{ml}), 1.2 \mathrm{ml}(0.8 \mathrm{mg} / \mathrm{ml})$ and $2.4 \mathrm{ml}(1.6 \mathrm{mg} / \mathrm{ml})$.

The sample solution at concentration 
of $0.25 \mathrm{~g} / \mathrm{ml}$ was pipetted $25 \mu \mathrm{L} .1 .25 \mathrm{ml}$ of distilled water was filled in before adding 5\% $\mathrm{NaNO}_{2} 75 \mu \mathrm{L}$ of $5 \% \mathrm{NaNO}_{2}$. The solution was shaken and left at room temperature for five minutes. $10 \% \mathrm{AlCl}_{3}$ at was added and the volume was adjusted to $150 \mu \mathrm{L}$. It was shaken before leaving at room temperature for $6 \mathrm{~min}$. $500 \mathrm{~mL}$ of $1 \mathrm{M} \mathrm{NaOH}$ was added before adding $775 \mu \mathrm{L}$ distillated water. Then the sample was measured by a Spectrophotometer at $510 \mathrm{~nm}$.

The total flavonoid content for each extract was then extrapolated from the absorbance curve of the standard solution. The results were described as mg Quercetin equivalent per $100 \mathrm{~g}$ of dry weight (mg QE/100g of DW).

\section{Chlorophyll a, chlorophyll b, total chlorophyll determination}

The seed coat of mungbeans contains chlorophyll and carotenoid. The protocols to determine the content of chlorophyll $a$, chlorophyll $b$ and total chlorophyll were optimized from Sumanta et al. (2014). A total of $0.3 \mathrm{ml}$ mungbean extract was pipetted into 2.7 $\mathrm{ml}$ of ethyl alcohol. The solution was subjected to spectrophotometer measurements at 664 , 649 and $470 \mathrm{~nm}$ wavelengths. Chlorophyll concentrations were calculated according to Equations 1, 2 and 3.

$$
\text { Chlorophyll } \mathrm{a}=(13.36)(\mathrm{A} 664)-(5.19)(\mathrm{A} 649)
$$$$
\text { (Eq 1) }
$$

Chlorophyll b = (27.43)(A649)- (8.12)(A664) (Eq 2)

Total chlorophyll $=$ Chlorophyll $a+$ Chlorophyll $b$

where (A664) is the absorbance at $664 \mathrm{~nm}$ wavelength and (A649) is the absorbance at $649 \mathrm{~nm}$ wavelength.

\section{Antioxidant Activity (DPPH Scavenging)}

DPPH radical scavenging assay was modified from the methods of Chan et al. (2007). A standard solution of BHA and L-ascorbic acid was prepared at concentrations of 1, 2, 10, 20, 30 and $40 \mu \mathrm{g} / \mathrm{ml}$. The desired concentrations were achieved by taking the following volumes of the stock solution and topping them up with ethyl alcohol to $1 \mathrm{ml}: 0.025 \mathrm{ml}$ (for $1 \mu \mathrm{g} / \mathrm{ml}), 0.05 \mathrm{ml}$ $(2 \mu \mathrm{g} / \mathrm{ml}), 0.25 \mathrm{ml}(10 \mu \mathrm{g} / \mathrm{ml}), 0.5 \mathrm{ml}(20 \mu \mathrm{g} /$ $\mathrm{ml}), 0.75 \mathrm{ml}(30 \mu \mathrm{g} / \mathrm{ml})$ and $0.4 \mathrm{ml}(40 \mu \mathrm{g} / \mathrm{ml})$.

The mungbean extracts were diluted from $0.25 \mathrm{~g} / \mathrm{ml}$ to the following concentrations by taking a desired volume and topping it up with ethyl alcohol to $1 \mathrm{ml}: 0.1 \mathrm{ml}(0.005 \mu \mathrm{g} / \mathrm{ml}), 0.5$ $\mathrm{ml}(0.025 \mu \mathrm{g} / \mathrm{ml}), 1.0 \mathrm{ml}(0.05 \mu \mathrm{g} / \mathrm{ml}), 2.0 \mathrm{ml}$ $(0.1 \mu \mathrm{g} / \mathrm{ml}), 5.0 \mathrm{ml}(0.25 \mu \mathrm{g} / \mathrm{ml}), 10.0 \mathrm{ml}(0.5$ $\mu \mathrm{g} / \mathrm{ml})$ and $20.0 \mathrm{ml}(0.8 \mu \mathrm{g} / \mathrm{ml})$.

Then $3 \mathrm{ml}$ of $0.1 \mathrm{mM}$ DPPH 2,2-diphenyl1-picrylhydrazyl was added and the mixtures were shaken for 30 minutes. The absorbance of the solutions were then measured with a spectrophotometer $(517 \mathrm{~nm})$ and the $\mathrm{IC}_{50}$ was established based on the BHA and L-ascorbic acid curve.

\section{Data Analysis}

The data were subjected to one-way analysis of variance (ANOVA) using the using STATISTIX 8 software. The means were compared using the Least Significant Difference (LSD) test $(\mathrm{P}<0.05)$.

\section{Results}

\section{Total Phenolic Content}

Different varieties of mungbean contained different concentrations of total phenolics. Chainat 36, Chainat 72, Chainat 84-1 had the highest concentration of total phenolics at between 50.57 and $57.47 \mathrm{mg} \mathrm{GAE} / 100 \mathrm{~g}$ of DW. The concentration of total phenolics in the sprouts at Day 4 was significantly higher than in seeds and sprouts at Day 1, 2 and 3. At Day 4 , the sprouts of Chainat 36 had a total phenolic concentration of $3,372.8 \mathrm{mg} \mathrm{GAE} / 100 \mathrm{~g}$ of DW, which was significantly higher than other varieties. Total phenolic content of Chainat 36 Day 4 sprouts also increased almost six-fold compared to Day 3, and was about three times higher than other varieties on Day 3 (Table 1). 
Table 1: Total phenolic content in seed and sprouts of mungbeans at Day 1, 2, 3 and 4 of germination (mg GAE/100 g of DW)

\begin{tabular}{|c|c|c|c|c|c|}
\hline \multirow{3}{*}{ Mungbean } & \multicolumn{5}{|c|}{ Total phenolic content } \\
\hline & \multirow{2}{*}{ Seeds } & \multicolumn{4}{|c|}{ Sprouts } \\
\hline & & Day 1 & Day 2 & Day 3 & Day 4 \\
\hline Chainat 36 & $44.72 \mathrm{bC}$ & $200.74 \mathrm{bC}$ & $326.92 \mathrm{bBC}$ & $548.21 \mathrm{bB}$ & $3,372.8 \mathrm{aA}$ \\
\hline Chainat 72 & $50.57 \mathrm{abE}$ & $207.04 \mathrm{abD}$ & $423.15 \mathrm{aC}$ & $680.63 \mathrm{aB}$ & $2,068.3 \mathrm{cA}$ \\
\hline Chainat 84-1 & $57.47 \mathrm{aD}$ & $211.75 \mathrm{abCD}$ & $345.10 \mathrm{bC}$ & $642.11 \mathrm{aB}$ & $2,764.6 \mathrm{bA}$ \\
\hline M.T.S 1 & $47.20 \mathrm{bD}$ & $196.36 \mathrm{bCD}$ & $324.30 \mathrm{bC}$ & $701.09 \mathrm{aB}$ & $2,483.4 \mathrm{bcA}$ \\
\hline Kamphaengsaen 2 & $51.50 \mathrm{abE}$ & $235.74 \mathrm{aD}$ & $354.01 \mathrm{bC}$ & $634.86 \mathrm{aB}$ & $1,324.3 \mathrm{dA}$ \\
\hline
\end{tabular}

abc Means within a column with different upper case letters are significantly different at $P<0.05$.

$\mathrm{ABC}$ Means within a row with different upper case letters are significantly different at $P<0.05$.

\section{Total Flavonoid Content}

Total flavonoids in seeds were very low, ranging from 3.93 to $4.53 \mathrm{mg}$ QE/100g of DW. Little variation was observed among the mungbean varieties. However, the concentration of total flavonoids increased sharply when the seeds began germinating. KPS 2 was observed to have total flavonoid content of $2,789.0 \mathrm{mg} \mathrm{QE} / 100 \mathrm{~g}$ of DW, while Chainat 36 had $6,808 \mathrm{mg}$ QE/100g of DW. At Day 4, total flavonoids in sprouts were significantly higher than that in seeds and sprouts at Day 1, 2 and 3 of germination. Chainat 36 and Chainat 72 showed no significant differences on the concentration of total flavonoids in seeds and sprouts at every day of germination (Table 2).

\section{Chlorophyll $a$}

Chlorophyll $a$ concentration was quite low in seeds and sprouts, ranging from $0.36-0.42 \mu \mathrm{g} /$ ml. M.T.S 1 contained significantly higher chlorophyll concentration $(0.38 \mu \mathrm{g} / \mathrm{ml})$ than other varieties, while Chainat 72 contained chlorophyll $a$ at $0.33 \mu \mathrm{g} / \mathrm{ml}$. There was not much difference of chlorophyll $a$ in different varieties of mungbeans both in seed and sprout form. During germination from Day 1 to Day 4, the chlorophyll $a$ content in sprouts was quite stable and almost the same in seeds (Table 3).

Table 2: Total flavonoid content in seeds and sprouts at Day 1, 2, 3 and 4 of germination (mg QE/100g of DW)

\begin{tabular}{llllll}
\hline \multirow{2}{*}{ Mungbean } & \multirow{5}{*}{ Seed } & \multicolumn{5}{c}{ Total flavonoids } \\
\cline { 2 - 6 } & & Day 1 & Day 2 & Day 3 & Day 4 \\
\cline { 2 - 6 } Chainat 36 & $3.93 \mathrm{abD}$ & $2,008.6 \mathrm{aC}$ & $1,730.9 \mathrm{bC}$ & $2,716.0 \mathrm{cB}$ & $6,808.6 \mathrm{aA}$ \\
Chainat 72 & $4.53 \mathrm{aD}$ & $2,012.9 \mathrm{aC}$ & $2,384.4 \mathrm{aC}$ & $4,231.3 \mathrm{aB}$ & $4,823.9 \mathrm{bA}$ \\
Chainat $84-1$ & $3.41 \mathrm{bcD}$ & $1,922.5 \mathrm{aC}$ & $1,868.6 \mathrm{bC}$ & $3,263.8 \mathrm{bB}$ & $5,271.9 \mathrm{bA}$ \\
M.T.S 1 & $3.65 \mathrm{bcD}$ & $1,664.6 \mathrm{bC}$ & $1,852.4 \mathrm{bC}$ & $3,079.8 \mathrm{bcB}$ & $4,757.5 \mathrm{bA}$ \\
KPS 2 & $3.18 \mathrm{cD}$ & $1,860.1 \mathrm{aC}$ & $1,805.7 \mathrm{bC}$ & $3,523.8 \mathrm{bA}$ & $2,789.8 \mathrm{cB}$ \\
\hline F-test & $*$ & $*$ & $*$ & $*$ & $* *$ \\
LSD & 0.30 & 91.44 & 188.21 & 238.19 & 463.26 \\
CV (\%) & 11.42 & 6.83 & 13.44 & 10.02 & 13.40 \\
\hline
\end{tabular}

abc Means within a column with different upper case letters are significantly different at $P<0.05$.

$\mathrm{ABC}$ Means within a row with different upper case letters are significantly different at $P<0.05$. 
Table 3: Cholorophyll $a$ in seeds and sprouts of mungbean at Day 1, 2, 3 and 4 of germination $(\mu \mathrm{g} / \mathrm{ml})$

\begin{tabular}{|c|c|c|c|c|c|}
\hline \multirow{3}{*}{ Mungbean } & \multicolumn{5}{|c|}{ Chlorophyll $a$} \\
\hline & \multirow{2}{*}{ Seed } & \multicolumn{4}{|c|}{ Sprout } \\
\hline & & Day 1 & Day 2 & Day 3 & Day 4 \\
\hline Chainat 36 & $0.36 \mathrm{bBC}$ & $0.32 \mathrm{abC}$ & $0.42 \mathrm{aA}$ & $0.37 \mathrm{aB}$ & $0.38 \mathrm{abB}$ \\
\hline Chainat 72 & $0.33 \mathrm{cBC}$ & $0.31 \mathrm{bC}$ & $0.37 \mathrm{bA}$ & $0.38 \mathrm{aA}$ & $0.36 \mathrm{abAB}$ \\
\hline Chainat 84-1 & $0.35 \mathrm{bB}$ & $0.32 \mathrm{abB}$ & $0.39 \mathrm{abA}$ & $0.40 \mathrm{aA}$ & $0.39 \mathrm{aA}$ \\
\hline M.T.S 1 & $0.38 \mathrm{aA}$ & $0.35 \mathrm{aC}$ & $0.38 \mathrm{abA}$ & $0.38 \mathrm{aAB}$ & $0.35 \mathrm{bBC}$ \\
\hline KPS 2 & $0.35 \mathrm{bAB}$ & $0.32 \mathrm{abB}$ & $0.38 \mathrm{bA}$ & $0.37 \mathrm{aAB}$ & $0.36 \mathrm{bAB}$ \\
\hline F-test & $*$ & $*$ & $*$ & $*$ & $*$ \\
\hline LSD & $7.845 \mathrm{E}-03$ & 0.01 & 0.01 & 0.02 & 0.01 \\
\hline CV(\%) & 3.10 & 6.31 & 6.95 & 8.43 & 5.68 \\
\hline
\end{tabular}

abc Means within a column with different upper case letters are significantly different at $P<0.05$.

$\mathrm{ABC}$ Means within a row with different upper case letters are significantly different at $P<0.05$.

\section{Chlorophyll $b$}

Chlorophyll $b$ in seeds of every mungbean variety was about $0.83-0.92 \mu \mathrm{g} / \mathrm{ml}$. There was not much difference in the concentration of chlorophyll $b$ among varieties. The concentration of chlorophyll $b$ increased after germination. At Day 4, chlorophyll $b$ in sprouts increased to around $1.06-1.30 \mu \mathrm{g} / \mathrm{ml}$, which was significantly higher than in seeds (Table 4).

Table 4: Chlorophyll $b$ in seeds and sprouts at Day 1, 2, 3 and 4 of germination $(\mu \mathrm{g} / \mathrm{ml})$

\begin{tabular}{|c|c|c|c|c|c|}
\hline \multirow{3}{*}{ Mungbean } & \multicolumn{5}{|c|}{ Chlorophyll $b$} \\
\hline & \multirow{2}{*}{ Seed } & \multicolumn{4}{|c|}{ Sprout } \\
\hline & & Day 1 & Day 2 & Day 3 & Day 4 \\
\hline Chainat 36 & $0.89 \mathrm{abC}$ & $0.89 \mathrm{abC}$ & $1.09 \mathrm{aB}$ & $1.04 \mathrm{bB}$ & $1.20 \mathrm{aA}$ \\
\hline Chainat 72 & $0.83 \mathrm{cC}$ & $0.85 \mathrm{bC}$ & $0.99 \mathrm{bB}$ & $1.02 \mathrm{bAB}$ & $1.08 \mathrm{bA}$ \\
\hline Chainat 84-1 & $0.87 \mathrm{bD}$ & $0.88 \mathrm{abD}$ & $1.08 \mathrm{abC}$ & $1.19 \mathrm{aB}$ & $1.30 \mathrm{aA}$ \\
\hline M.T.S 1 & $0.92 \mathrm{abB}$ & $0.94 \mathrm{aB}$ & $1.02 \mathrm{abA}$ & $1.04 \mathrm{bA}$ & $1.05 \mathrm{bA}$ \\
\hline KPS 2 & $0.89 \mathrm{aB}$ & $0.89 \mathrm{abB}$ & $1.03 \mathrm{abA}$ & $1.06 \mathrm{bA}$ & $1.06 \mathrm{bA}$ \\
\hline
\end{tabular}

abc Means within a column with different upper case letters are significantly different at $P<0.05$.

$\mathrm{ABC}$ Means within a row with different upper case letters are significantly different at $P<0.05$.

\section{Total chlorophyll}

Total chlorophyll in seeds was quite low in all varieties $(1.16-1.30 \mu \mathrm{g} / \mathrm{mL})$. It increased with time after germination. At Day 4, total chlorophyll in every variety was significantly higher than in seeds, but the increase was not much. The biggest increase in total chlorophyll concentration between seeds and sprouts was observed in Chainat 84-1, where it jumped from $1.22 \mu \mathrm{g} / \mathrm{ml}$ to $1.70 \mu \mathrm{g} / \mathrm{ml}$ (Table 5). 
Table 5: Total chlorophyll in seeds and sprouts at Day 1, 2, 3 and 4 of germination $(\mu \mathrm{g} / \mathrm{ml})$

\begin{tabular}{|c|c|c|c|c|c|}
\hline \multirow{3}{*}{ Mungbean } & \multicolumn{5}{|c|}{ Total chlorophyll } \\
\hline & \multirow{2}{*}{ Seed } & \multicolumn{4}{|c|}{ Sprout } \\
\hline & & Day 1 & Day 2 & Day 3 & Day 4 \\
\hline Chainat 36 & $1.25 \mathrm{bC}$ & $1.22 \mathrm{abC}$ & $1.51 \mathrm{aAB}$ & $1.40 \mathrm{bB}$ & $1.58 \mathrm{abA}$ \\
\hline Chainat 72 & $1.16 \mathrm{cB}$ & $1.16 \mathrm{bB}$ & $1.36 \mathrm{bA}$ & $1.40 \mathrm{bA}$ & $1.45 \mathrm{bcA}$ \\
\hline Chainat 84-1 & $1.22 \mathrm{bC}$ & $1.20 \mathrm{abC}$ & $1.47 \mathrm{abB}$ & $1.60 \mathrm{aA}$ & $1.70 \mathrm{aA}$ \\
\hline M.T.S 1 & $1.30 \mathrm{aB}$ & $1.29 \mathrm{aB}$ & $1.40 \mathrm{abA}$ & $1.41 \mathrm{bA}$ & $1.40 \mathrm{cA}$ \\
\hline KPS 2 & $1.25 \mathrm{abBC}$ & $1.22 \mathrm{abC}$ & $1.41 \mathrm{abAB}$ & $1.44 \mathrm{abA}$ & $1.42 \mathrm{cAB}$ \\
\hline
\end{tabular}

abc Means within a column with different upper case letters are significantly different at $P<0.05$.

ABC Means within a row with different upper case letters are significantly different at $P<0.05$.

\section{Antioxidant Activity}

The DPPH radical scavenging in seeds was low at about $28-37 \mathrm{mg}$. It was $28.11 \mu \mathrm{g} / \mathrm{ml}$ in Chainat $72,30.66 \mu \mathrm{g} / \mathrm{ml}$ in Chainat $84-1$ and $37.63 \mu \mathrm{g} /$ $\mathrm{ml}$ in Chainat 36. Chainat 72 and Chinat 84-1 contained significantly higher antioxidant activity than other varieties. During germination, antioxidant activity increased sharply, the sprouts at Day 4 contained antioxidant activity significantly higher than that in seeds by almost 30-fold. At Day 4, the highest DPPH radical scavenging was found in sprouts of M.T.S 1, but it was not much different with other varieties. However, antioxidant activity in all sprouts increased quite steadily from Day 1 to Day 4 (Table 6).

Table 6: Antioxidant activity in seeds and sprouts at Day 1, 2, 3 and 4 of germination (mg/ml).

\begin{tabular}{|c|c|c|c|c|c|}
\hline \multirow{3}{*}{ Mungbean } & \multicolumn{5}{|c|}{$\mathrm{IC}_{50}$} \\
\hline & \multirow{2}{*}{ Seed } & \multicolumn{4}{|c|}{ Sprout } \\
\hline & & Day 1 & day 2 & day 3 & day 4 \\
\hline Chainat 36 & $37.63 \mathrm{aA}$ & $3.75 \mathrm{aB}$ & $2.80 \mathrm{aB}$ & $1.95 \mathrm{aB}$ & $0.90 \mathrm{cB}$ \\
\hline Chainat 72 & $28.11 \mathrm{cA}$ & $3.02 \mathrm{bcB}$ & $2.18 \mathrm{bC}$ & $1.44 \mathrm{cD}$ & $1.10 \mathrm{bD}$ \\
\hline Chainat 84-1 & $30.66 \mathrm{bcA}$ & $2.74 \mathrm{cdB}$ & $2.23 \mathrm{bBC}$ & $1.55 \mathrm{bcBC}$ & $1.52 \mathrm{aC}$ \\
\hline M.T.S 1 & $33.53 \mathrm{abA}$ & $2.46 \mathrm{~dB}$ & $2.30 \mathrm{bBC}$ & $1.61 \mathrm{bBC}$ & $0.83 \mathrm{dC}$ \\
\hline KPS 2 & $33.07 \mathrm{abA}$ & $3.23 \mathrm{bB}$ & $1.97 \mathrm{cB}$ & $1.42 \mathrm{cC}$ & $0.94 \mathrm{cC}$ \\
\hline F-test & $*$ & $* *$ & $* *$ & $* *$ & $* *$ \\
\hline LSD & 2.21 & 0.17 & 0.08 & 0.07 & 0.02 \\
\hline CV(\%) & 9.57 & 7.95 & 4.67 & 6.38 & 2.92 \\
\hline
\end{tabular}

abc Means within a column with different upper case letters are significantly different at $P<0.05$.

$\mathrm{ABC}$ Means within a row with different upper case letters are significantly different at $P<0.05$. 


\section{Discussion}

There was low variation of antioxidants, total phenolics, total flavonoids, chlorophyll $a$, chlorophyll $b$ and total chlorophyll in seeds of four mungbean varieties in this study. This confirmed earlier observations by Ebert et al. (2017) that that there was less variation in antioxidant activity among mungbean genotypes at sprouting stage, with the exception of VI000197 having inferior content. There was not much difference of chlorophyll $a$, $b$, and total chlorophyll concentration in different varieties of mungbean both in seeds and sprouts. Chlorophyll $a$, chlorophyll $b$, and total chlorophyll were low and did not increase with germination day. Earlier observations in mungbean sprouts from Afghanistan, Taiwan, Thailand by Ebert et al. (2017) indicated that their total carotenoids were lower compared with grain.

During germination, especially at Day 4, total phenolic and flavonoid contents were very high, particularly in Chainat 36, which were almost 10 - to 15 -fold more than the seeds This was probably due to the accumulation of reactive oxygen species (ROS) (Job et al., 2005). Plants, therefore, would attempt to maintain the balance of ROS in cells by synthesizing phenolics and flavonoids (Chen et al., 2014; Chen et $a l ., 2019)$. The increase of phenolics differed among the types of seed (Cevallos-Casals \& Cisneros-Zevallos, 2010). One study had found it increasing by $2,010 \%$ in sprouts and $11 \%$ in kale at Day 7 . The study by Nair et al., (2015) identified ferulic acid (1,540-3,400 $\mathrm{mg} / \mathrm{g})$ as the phenolic compound in mungbean seeds. Kim et al. (2013) showed that the IT104818 variety of the Korean mungbean contained higher phenolic compounds than other varieties. The concentration of total phenolics and total flavonoids in the sprouts in this study could be clearly compared with other studies if the experiment was extended beyond Day 4.

The total phenolic content in seeds of all mungbean varieties in this study was significantly higher than the Chinese toon bud, perilla leaf, loosestrife, soybean (green) and pepper leaf (Deng et al., 2013). When compared with vegetables like the ruby red lettuce ( $483 \mathrm{mg}$ GAE/100 $\mathrm{g}$ of DW), the total phenolic content was far lower, but it was still higher than the garden cress (12.8 mg GAE/100 $\mathrm{g}$ of DW) and wild rocket leaves $(8.1 \mathrm{mg} \mathrm{GAE} / 100 \mathrm{~g}$ of DW) (Santos et al., 2014).

Total flavonoids in mungbean seeds was very low compared with sprouts at Day 4. This figures were comparable with the findings of a study on 11 vegetables from west Java, Indonesia, where the flavonoid content was between 4.0 and $832 \mathrm{mg} \mathrm{QE} \mathrm{/100} \mathrm{g} \mathrm{dry} \mathrm{weight}$ (Jiménez-Aguilar and Grusak, 2017).

The DPPH radical scavenging in seed of every variety of mungbean was low, but sharply increased with germination. They increased with the increase of total phenolic and total flavonoid content. At Day 4, total phenolics, total flavonoids and antioxidant activity were highest in every mungbean variety. The result of this research was in contrast with the review and report by Ebert et al. (2017) on another antioxidant like vitamin $\mathrm{C}$, which found the content to be considerably lower at the fully mature stage of sprouting. In this study, DPPH radical scavenging might have increased during germination from the increase of total phenolics and total flavonoids. In this study, antioxidant activity in mungbean seeds was $28.11-37.63 \mathrm{mg} / \mathrm{ml}$, and it was $0.83-1.52 \mathrm{mg} / \mathrm{ml}$ in sprouts at Day 4 . Whereas in leafy vegetable of Alternanthera sessilis in India, percentages of DPPH radical scavenging activity was 57.6 and $64.73 \%$ after extraction by acetone and ethyl acetate, respectively (Kota et al., 2017). However, little variation in antioxidant activity was found both in seeds and sprouts. Our results are in agreement with Ebert et al. (2017), who reported little variation of mungbean genotypes at the sprouting stage.

\section{Conclusion}

Antioxidants studied in mungbean seeds were low and there was low variation among varieties. Chainat 72 and Chinat 84-1 had the highest 
seed antioxidant activity than other varieties, but still in low variation. During germination, especially on Day 4, total phenolic and total flavonoid contents were very high, particularly in Chainat 36. They were almost 10- and 15-fold compared with the seeds, respectively. Chinat 36, Chainat 72, and Chainat 84-1, contained the highest concentration of total phenolic and total flavonoid contents than other varieties.

\section{Acknowledgements}

The authors like to thank Mahasakham University, Thailand, for providing the grant for this study. Special gratitude also goes to Associate Professor Dr. David W. Turner for his critical comments.

\section{Reference}

Anwar, F., Latif, S., Przybylski, R., Sultana, B., \& Ashraf, M. (2007). Chemical composition and antioxidant activity of seeds of different cultivars of mung bean. Journal of Food Science, 72, 503-510.

Cevallos-Casals, B. A., \& Cisneros-Zevallos, L. (2010). Impact of germination on phenolic content and antioxidant activity of 13 edible seed species. Food Chemistry, 119, 14851490.

Chan, E. W. C., Lim, Y. Y., \& Omar, M. (2007). Antioxidant and antibacterial activity of leaves of Etlingera species (Zingiberaceae) in Peninsular Malaysia. Food Chemistry, 104, 1586-1593.

Chen, L., Mingshuang, X., Yanyan, Z., Yanyan, Z., Yejun, M., Jiping., S., \& Lin, S. (2014). Growth promotion and induction of antioxidant system of tomato seedlings (Solanum lycopersicum L.) by endophyte TPs-04 under low night temperature. Scientia Horticulturae, 176, 143-150.

Chen, L., Tan, J. T. G., Zhao, X., Yang, D., \& Yang, H. (2019). Energy regulated enzyme and non-enzyme-based antioxidant properties of harvested organic mung bean sprouts (Vigna radiata). LWT-Food Science and Technology, 107, 228-235.

Deng, G. F., Lin, X., Xu, X. R., Gao, L. L., Xie, J. F., \& Li, H. B. (2013). Antioxidant capacities and total phenolic contents of 56 vegetables. Journal of Functional Foods, 5 , 260-266.

Department of Agriculture. (n.d.). New varieties of mungbean (in Thai). Research files. Department of Agriculture. http://www.doa. go.th/research/showthread.php?tid=467.

Ebert, A. W., Chang, C. H., Yan, M. R., \& Yang, R. Y. (2017). Nutritional composition of mungbean and soybean sprouts compared to their adult growth stage. Food Chemistry Journal, 237, 15-22.

Javanmardi, J., Stushnoft, C., Locke, E., \& Vivanco, J. M. (2003). Antioxidant activity and total phenolic content of Iranian Ocimum Accessions. Food Chemistry, 83, 547-550.

Jiménez-Aguilar, D. M., \& Grusak, M. A. (2017). Minerals, vitamin C, phenolics, flavonoids and antioxidant activity of Amaranthus leafy vegetables. Journal of Food Composition and Analysis, 58, 33-39.

Job, C., Rajjou, L., Lovigny, Y., Belghazi, M., \& Job, D. (2005). Patterns of protein oxidation in Arabidopsis seeds and during germination. Plant Physiology, 138, 790802.

Kim, J. K., Kim., E. H., Lee, O. K., Park, S. Y., Lee, B., Kim, S. H., Park, I., \& Chung, I. M. (2013). Variation and correlation analysis of phenolic compounds in mungbean (Vigna radiata L.) varieties. Food Chemistry, 141, 2998-2997.

Kota, S., Govada, V. R., Anantha, R. K., \& Verma, M. K. (2017). An investigation into phytochemical constituents, antioxidant, antibacterial and anti-cataract activity of Alternanthera sessilis, a predominant wild leafy vegetable of South India. Biocatalysis and Agricultural Biotechnology, 10, $197-$ 203. 
Kudre, T. G., Benjakul, S., \& Kishimura, H. (2013). Comparative study on chemical compositions and properties of protein isolates from mung bean. Journal of the Science of Food and Agriculture, 93(10), 2429-2436.

Lim, T. K. (2012). Edible medicinal and nonmedicinal plants, black bean and bambara groundnut. Fruits. Dordrecht Heidelberg London New York: Springer. pp. 966-967.

Lin, X., \& Li, W. Z. (1997). The research of mung bean SOD oral liquid. Food Science, 18, 25-26.

Liu, C. Y., Chen, X. Z., Wang, S. H., Wang, L. X., Sun, L., Mei, L. X., \& Xu, N. (2006). The genetic diversity of mungbean germplasm in China. Journal of Plant Genetic Resource, 7, 459-463.

Nair, K. M., Yang, R. Y., Easdown, W. J., Thavarajah, P., Hughes, J. A., \& Keatinge, J. D. H. (2013). Biofortification of mungbean (Vigna radiata) as a whole food to enhance human Health. Journal of the Science of Food and Agriculture, 93, 1805-1813.

Nair, R. M., Thavarajah, D., Thavarajah, P., Giri, R. R., Ledesma, D., Yang, R. Y., Hanson, P., Easdown, W., Hughes, J. A., \& Keatings, J. D. H. (2015). Mineral and phenolic concentrations of mungbean [Vigna radiata (L.) R. Wilczek var. radiata] grown in semi-arid tropical India. Journal of Food Composition and Analysis, 39, 23-32.

Pizzino, G., Irrera, N., Cucinotta, M., Pallio, G., Mannino, F., Arcoraci, V., Squadrito, F., Altavilla, D., \& Bitto, A. (2017).
Oxidative stress: Harms and benefits for human health. Oxidative medicine and cellular longevity. https://doi. org/10.1155/2017/8416763.

Santos, J., Oliveira, M. B. P. P.O., Ibáñez, E., \& Herrero, M. (2014). Phenolic profile evolution of different ready-to-eat babyleaf vegetables during storage. Journal of Chromatography A, 1327, 118-131.

Shi, Z., Yao, Y., Zhu, Y., \& Ren, G. (2016). Nutritional composition and antioxidant activity of twenty mung bean cultivars. China, Crop Journal, 4, 398-406.

Sumanta, N., Haque, C. I., Nishika, J., \& Suprakash, R. (2014). Spectrophotometric analysis of chorophylls and carotenoids from commonly grown fern species by using various extracting solvents. Research Journal of Chemical Sciences, 4, 63-69.

Tang, D., Dong, Y., Ren, H., Li, L., \& He, C. (2014). A review of phytochemistry, metabolite changes, and medicinal uses of the common food mungbean and its sprout (Vigna radiata). Chemistry Central Journal, 8(4), 1-10.

Wu, J. Q., Kosten, T. R., \& Zhang, X. Y. (2013). Free radicals, antioxidant defense system, and schizophrenia. Progress in Neuro-psychopharmacology \& Biological Psychiatry. 46, 200-206.

Yang, J., Martinson, T. E., \& Liu, R. H. (2009). Phytochemical profiles and antioxidant activities of wine grapes. Food Chemistry, 116, 332-339. 